\title{
Federal public health strategies to minimize the importation of communicable diseases into Canada
}

\author{
Bhatia $\mathrm{N}^{1}$, Sarwal $\mathrm{S}^{2 \star}$, Robinson $\mathrm{H}^{2}$, Geduld $\mathrm{J}^{2}$, Huneault $\mathrm{F}^{2}$, Schreiner $\mathrm{H}^{2}$, Collins $\mathrm{S}^{2}$, Hickey $\mathrm{R}^{2}$ \\ ${ }^{1}$ Schulich School of Family Medicine and Dentistry, University of Western Ontario, London, ON \\ ${ }^{2}$ Health Security Infrastructure Branch, Public Health Agency of Canada, Ottawa, ON \\ Correspondence: shelly.sarwal@phac-aspc.gc.ca
}

\begin{abstract}
Background: The global spread of communicable diseases is a growing concern largely as a result of increased international travel. In Canada, although most public health management of communicable diseases occurs at the front line, the federal government also takes actions to prevent and mitigate their importation.

Objective: To describe the role of the Public Health Agency of Canada (PHAC) in minimizing the importation of communicable diseases through preventive measures taken before travellers leave Canada and through early detection and prompt containment measures taken when travellers arrive in the country with a potential communicable disease.

Interventions: PHAC works to minimize the importation of communicable diseases into Canada by developing evidence-based travel health advice and targeted outreach activities geared to the public and to health care professionals. On the basis of the Quarantine Act and the International Health Regulations (2005), PHAC also conducts inspections of conveyances such as aircraft and boats and works with partners to conduct border screening to assess ill travellers entering the country.

Conclusion: PHAC plays an important role in preventing and minimizing the importation of communicable diseases into Canada in conjunction with clinicians, public health authorities at all levels of government and other federal government departments.
\end{abstract}

\section{Introduction}

According to the World Bank, international travel has been steadily increasing and it is estimated that in 2011, international tourist arrivals exceeded one billion (1). The continuous movement of people and goods into Canada by air, land and sea has resulted in an ever-present risk of importing communicable diseases.

In Canada, communicable diseases are managed primarily at the provincial, territorial and local levels. However, many federal government departments are also involved in minimizing the importation of human and animal pathogens, toxins, vectors and reservoirs of communicable diseases (Table 1). There are extensive federal legislations that direct government departments to address this (2,3-8). For example, Acts and regulations administered by the Public Health Agency of Canada (PHAC) include the Human Pathogens Importation Regulations (2), the Quarantine Act (3) and the Potable Water Regulations for Common Carriers (4). 
Table 1: Examples of activities by federal departments to minimize the importation of communicable diseases into Canada

\begin{tabular}{|c|c|c|c|}
\hline Public Health Agency of Canada & $\begin{array}{l}\text { Canadian Food } \\
\text { Inspection Agency }\end{array}$ & $\begin{array}{l}\text { Canada Border } \\
\text { Services Agency }\end{array}$ & $\begin{array}{l}\text { Citizenship and } \\
\text { Immigration } \\
\text { Canada }\end{array}$ \\
\hline $\begin{array}{l}\text { - Provide travel health advice and } \\
\text { recommendations to individuals and health } \\
\text { professionals. } \\
\text { - Assess ill individuals at points of entry. } \\
\text { - Inspect conveyances, ancillary services } \\
\text { and terminals. } \\
\text { - Regulate importation of human pathogens. } \\
\text { - Contribute to the development and } \\
\text { maintenance of core public health capacity } \\
\text { to protect citizens from public health risks } \\
\text { and is the national focal point for the } \\
\text { International Health Regulations. }\end{array}$ & $\begin{array}{l}\text { Regulate the } \\
\text { importation of food } \\
\text { products. } \\
\text { Regulate the } \\
\text { importation of } \\
\text { plants and plant } \\
\text { products. } \\
\text { Regulate the } \\
\text { importation of live } \\
\text { animals and animal } \\
\text { products and by- } \\
\text { products. } \\
\text { Inspect livestock at } \\
\text { points of entry. }\end{array}$ & $\begin{array}{l}\text { Conduct initial } \\
\text { screening of } \\
\text { people, food, } \\
\text { cargo, baggage } \\
\text { and agricultural } \\
\text { products at } \\
\text { points of entry }\end{array}$ & $\begin{array}{l}\text { Screen } \\
\text { immigrants and } \\
\text { certain other } \\
\text { classes of } \\
\text { foreign nationals } \\
\text { for selected } \\
\text { infectious } \\
\text { diseases prior to } \\
\text { arrival in } \\
\text { Canada. }\end{array}$ \\
\hline
\end{tabular}

The objective of this article is to provide an overview of PHAC's roles and responsibilities in minimizing the importation of communicable diseases into Canada through preventive measures taken for travellers and modes of transportation prior to leaving the country as well as measures taken when ill people enter the country. It does not include, nor is it meant to diminish, the roles of local, provincial and territorial authorities or other federal government departments.

\section{The federal public health strategy}

PHAC minimizes the importation of communicable diseases into Canada through preventive and response activities, aimed at travellers and modes of transportation. Travel health information is available to individuals before they leave the country. Conveyances, or international modes of transportation are inspected and public health risks are addressed. All travellers are screened on arrival to Canada. Other papers in this issue address how PHAC manages new legislation that sets out a risk-based licensing framework to improve federal oversight of human pathogens and toxins in Canada (9), and how PHAC can assist in the rapid response to manage and contain an infection when it does enter the country (10).

\section{Minimizing risks before leaving Canada}

PHAC provides travel health advice and recommendations to travellers and to health care professionals. Advice is also provided to conveyance operators. Inspections are conducted of conveyances, ancillary services (such as flight kitchens) and terminals.

\section{Information for travellers}

PHAC's Travel Health Program publishes travel health notices, travel-related disease fact sheets and travel health recommendations by destination on the PHAC website and travel.gc.ca (11). Travel health notices notify the public about health events including outbreaks that may be of concern to travellers. The notices provide a level of risk and recommend measures that can be taken by travellers (Table 2). 
Table 2: Travel health notices and levels of risk

\begin{tabular}{|c|c|c|}
\hline Risk level & Explanation & Example (when) \\
\hline $\begin{array}{l}\text { 1. Practice } \\
\text { usual } \\
\text { precautions }\end{array}$ & $\begin{array}{l}\text { - Advises travellers to practice usual precautions (e.g., routine } \\
\text { vaccinations, hand washing, protective measures to avoid } \\
\text { mosquito bites). }\end{array}$ & $\begin{array}{l}\text { Chikungunya virus } \\
\text { infection in the } \\
\text { Caribbean } \\
\text { (still current as of } \\
\text { December 2015) }\end{array}$ \\
\hline $\begin{array}{l}\text { 2. Practice } \\
\text { enhanced } \\
\text { precautions }\end{array}$ & $\begin{array}{l}\text { - Recommends that travellers practice special precautions, such } \\
\text { as receive additional vaccines. } \\
\text { - Would be issued if there was an outbreak in a limited } \\
\text { geographic location, a newly identified disease in the region, or } \\
\text { a change in the existing pattern of disease. }\end{array}$ & $\begin{array}{l}\text { World Health } \\
\text { Organization (WHO) } \\
\text { temporary polio } \\
\text { vaccine } \\
\text { recommendations } \\
\text { (still current as of } \\
\text { December 2015) }\end{array}$ \\
\hline $\begin{array}{l}\text { 3. Avoid non- } \\
\text { essential travel }\end{array}$ & $\begin{array}{l}\text { - A warning to avoid non-essential travel in order to protect the } \\
\text { health of Canadian travellers and the Canadian public. } \\
\text { - Outlines specific precautions to take when visiting the region } \\
\text { and what to do if you become ill during or after travel. } \\
\text { - Would be issued during a large-scale outbreak in a large } \\
\text { geographic area, or if there is increased risk to the traveller and } \\
\text { an increased risk of spreading disease to other groups including } \\
\text { the Canadian public. }\end{array}$ & $\begin{array}{l}\text { Ebola virus disease in } \\
\text { West Africa (still } \\
\text { current in Guinea and } \\
\text { Sierra Leone as of } \\
\text { December 2015) }\end{array}$ \\
\hline $\begin{array}{l}\text { 4. Avoid all } \\
\text { travel }\end{array}$ & $\begin{array}{l}\text { - Advises travellers to avoid all travel in order to protect the } \\
\text { health of the Canadian public. } \\
\text { - Would be issued if there is a high risk of spread of disease to } \\
\text { the general public regardless of measures taken while } \\
\text { travelling. Avoiding travel will limit the spread of the disease in } \\
\text { Canada and internationally. }\end{array}$ & Never issued. \\
\hline
\end{tabular}

Information on measures to take during mass gathering events is also provided through targeted outreach. For example, specific information is provided to Canadians planning to attend the Hajj, the Muslim pilgrimage to Mecca, Saudi Arabia. During the Hajj, there is increased risk of transmission of certain communicable diseases, such as meningococcal meningitis and respiratory infections $(12,13)$. Beginning in 2014, materials such as posters and information sheets were developed and translated into five languages (French, English, Arabic, Urdu and Turkish). These materials were distributed to stakeholders, including physicians and community centres in Muslim communities, mosques, Islamic schools and Canadian travel agencies authorized to issue visas for Hajj pilgrims. In 2014, these travel agencies issued approximately 3,500 visas to attend the Hajj.

Finally, during specific public health events such as the Severe Acute Respiratory Syndrome (SARS), pandemic H1N1, and more recently the Ebola outbreak in West Africa, information was provided to travellers in airports through posters and on airport monitors (14). Travel health information was also available on the travel.gc.ca website (11) and through social media, such as Facebook and Twitter.

\section{Information for health professionals}

PHAC provides secretariat and epidemiologic support to the Committee to Advise on Tropical Medicine and Travel (CATMAT), an expert advisory body that assists PHAC in developing travel health recommendations for travellers and health professionals (15). CATMAT produces evidence-based recommendations on the prevention and treatment of infectious diseases and other health hazards that Canadian travellers may encounter internationally. CATMAT statements and recommendations on travel health diseases, conditions and special populations are available on the PHAC website.

\section{Minimizing risk on conveyances}

A conveyance is a mode of transportation such as aircraft, trains, cruise ships and ferries (4). PHAC's Travelling Public Program works with the international conveyance sector largely aircraft and ships. PHAC 
conducts risk assessments of conveyances and ancillary services, including flight kitchens and terminals, and works with operators to correct any identified public health risks. Inspections focus on potable water, food, sanitation and vector control. Other activities include potable water sampling on conveyances under the Potable Water Regulations for Common Carriers (4) and food handler and sanitation training for industry employees.

The Travelling Public Program has a compliance inspection program for cruise ships that visit Canadian ports (16). Unannounced inspections are conducted on participating cruise ships travelling in Canadian waters. The scoring system is based on 41 inspection items with a total value of 100 points. A satisfactory score is 86 points out of a possible 100 points. A score of 85 or lower is not satisfactory and requires a reinspection within the following month. An unsatisfactory score does not mean, however, that the travelling public is exposed to any imminent risk to his/her health.

\section{Minimizing the importation of communicable diseases}

In the International Health Regulations (2005) (IHR (2005), a point of entry is defined as a passage for international entry or exit for travellers, conveyances and goods and includes airports, marine ports and land crossings (17). Many of the public health measures taken at points of entry are conducted under the umbrella of the IHR (2005), an international treaty that Canada has signed (18). The purpose of the IHR (2005) is to prevent, protect against, control and respond to the international spread of disease while avoiding unnecessary interference with international traffic and trade. Under the IHR (2005), Canada is obligated to take health measures at points of entry in order to limit the spread of public health risks.

To determine whether Canada met IHR (2005) requirements at points of entry, the capacity to detect and respond to public health risks (including infectious diseases) was assessed at five points of entry. These points of entry were selected based on volume of travellers and geographic representation and included the Vancouver International Airport, Toronto Pearson International Airport, Montréal-Trudeau International Airport, Metro Vancouver Cruise Ship Terminal and the Halifax Cruise Ship Terminal. These points of entry met WHO requirements and are therefore considered designated points of entry under the IHR (2005). WHO requirements for designated points of entry include having staff and resources available to assess, care for and transport ill travellers and animals and the capacity to inspect conveyances and terminals for public health risks. Furthermore, these IHR-designated Canadian points of entry routinely conduct exercises to assess their response capacity and to ensure that they continue to meet IHR (2005) requirements.

\section{Prior to arrival in Canada}

Prior to entering Canadian waters, all international cruise ships report their gastrointestinal illness (GI) rates in passengers and crew to PHAC's Travelling Public Program. Immediate reporting is required if the GI illness rates are above key public health thresholds. PHAC works with the cruise ship operator to mitigate the risk to the other passengers or crew by ensuring the cruise ship has implemented its outbreak prevention procedures. PHAC environmental health officers, who are certified Public Health Inspectors, may conduct an onboard investigation.

Additionally, aircraft are required to report any illnesses or deaths on board to the airport authority prior to arrival. These cases are then assessed by PHAC quarantine officers, who are registered nurses (3).

\section{Upon arrival in Canada}

All travellers arriving in Canada are obligated to present themselves to a Canadian Border Services Agency officer where they are screened for illness as well as for any food, plant and animal products in their possession. As specified in the quarantine Act, if a traveller screens positive for a potential communicable disease that poses a public health risk, he/she is referred to a quarantine officer for further assessment, which includes a history and temperature check (3). Quarantine officers are stationed in selected airports across the country which have a high volume of international travellers. If the ill traveller arrives at one of these airports, this assessment is conducted in person. If the ill traveller is at a point of entry other than these airports, such as a marine port or a land crossing, this assessment is conducted by telephone. 
If the quarantine officer suspects that the traveller has a communicable disease that poses a public health risk, certain measures can be taken, e.g., the traveller can be ordered to report to a nearby hospital for further evaluation or can be ordered to report to the local public health authority within a specified amount of time for follow-up. The Quarantine Officer will coordinate with the local public health authority, emergency services and the hospital to manage the ill traveller.

Environmental health officers also responds to incidents on board conveyances if food, water or sanitation is of concern. For example, environmental health officers may advise aircraft groomers on cleaning spills of body fluids or may investigate reports of vectors, such as rats on ships.

\section{After arrival in Canada}

PHAC provides financial support to the Canadian Travel Medicine Network (CanTravNet), a network of Canadian clinical experts in travel and tropical medicine (19). CanTravNet sites are members of the GeoSentinel Global Surveillance Network, an international network that collects data on returned travellers and immigrants as a sentinel network for global emerging infections.

When a serious infection or outbreak is identified, PHAC has the capacity to deploy a rapid response team to help local and provincial or territorial health authorities to assist in the protection of health care workers and to treat and limit the spread of the disease (18). Under the IHR (2005), information on certain public health events, including communicable diseases, may be shared with the World Health Organization to facilitate international collaboration during a public health response $(17,18)$.

\section{Discussion}

PHAC has a strong federal public health strategy to minimize the importation of communicable diseases into Canada based on health promotion and prevention, early detection and prompt response. PHAC meets its mandate by working in close collaboration with clinical care and public health authorities from a local through to an international level, as well as with other federal departments such as the Canadian Border Services Agency and the Canadian Food Inspection Agency.

One of the components of PHAC's strategy is the entry border screening of travellers. Travellers are screened based on signs and symptoms, rather than laboratory testing. Upon arrival, travellers may be asymptomatic, either in the incubation period or have a subclinical infection, have mild symptoms, use antipyretics to reduce fever, or may not report their symptoms. Because cases may be missed, entry screening has been described as ineffective and resource-intensive (13,20-22). However, the efficacy of border screening is difficult to evaluate (23). One study has shown that entry screening may delay local transmission of a novel influenza strain by one to two weeks, time which could be used for further community preparation for an epidemic (21). In addition, visible border screening and control may increase public confidence, awareness and compliance. While entry screening of travellers at borders has limitations, it is only one piece of PHAC's strategy to minimize the importation of communicable diseases into Canada.

New infectious disease threats will continue to emerge in the context of globalization and increased travel, however an integrated system is in place to minimize the importation of communicable diseases at the borders and to protect and promote our national health security. PHAC regularly assesses and develops its strategy. Recent developments with human pathogen legislation (2) and rapid response teams (10) are examples of how PHAC continually strengthens its federal capacity to work with others in the fight against infectious diseases.

\section{Conclusion}

Multiple federal government departments work together at the Canadian border to assess people, animals, food, cargo, baggage, conveyances, containers, goods and parcels to prevent infections, toxins, vectors and potential reservoirs of infectious diseases from entering Canada. PHAC will continue to offer and advance health promotion and prevention activities, such as travel health alerts and travel health recommendations for clinicians and participates in inspections, surveillance and response activities to minimize the importation of communicable diseases into Canada. 


\section{Acknowledgements}

We would like to thank and acknowledge all the people who work in these programs to help keep Canadians safe.

\section{Conflict of interest}

None

\section{Funding}

Funding for these federal programs is provided by the Government of Canada.

\section{References}

(1) The World Bank. International tourism, number of arrivals. Washington DC: The World Bank; 2015. http://data.worldbank.org/indicator/ST.INT.ARVL/countries/1W?display=graph.

(2) Government of Canada. Human Pathogens and Toxins Regulations (HPTR). SOR/2015-44 October $27,2015$. http://gazette.gc.ca/rp-pr/p2/2015/2015-03-11/html/sor-dors44-eng.php.

(3) Government of Canada. Quarantine Act (S.C. 2005, c.20). http://laws.justice.gc.ca/eng/acts/Q-1.1/.

(4) Government of Canada. Potable Water Regulations for Common Carriers (C.R.C., C. 1105). http://laws-lois.justice.gc.ca/eng/regulations/C.R.C.,_c._1105/.

(5) Government of Canada. Food and Drugs Act (R.S.C., 1985, c. F-27). 20. http://laws-lois.justice.gc.ca/eng/acts/F-27/.

(6) Government of Canada. Health of Animals Act (S.C. 1990, c.21). http://laws-lois.justice.gc.ca/eng/acts/H-3.3/.

(7) Government of Canada. Plant Protection Act (S.C. 1990, c. 22). http://laws-lois.justice.gc.ca/eng/acts/P-14.8/.

(8) Government of Canada. Immigration and Refugee Protection Act (S.C. 2001, c. 27). http://laws-lois.justice.gc.ca/eng/acts/i-2.5/index.html.

(9) Labrie C, Lecordier S. Regulatory oversight of human pathogens and toxins in Canada. CCDR. 2015 Dec 17;41(S6):9-13.

(10) Lior LY, Njoo H. Ready to Go! Canada's new Rapid Response Team. CCDR. 2015 Dec 17;41(S6):14-18

(11) Public Health Agency of Canada. Travel health notices. Ottawa ON: PHAC; 2015. http://www.phac-aspc.gc.ca/tmp-pmv/index-eng.php.

(12) Memish ZA. The Hajj: Communicable and non-communicable health hazards and current guidance for pilgrims. Euro Surveill. 2010;15(39):pii=19671. http://www.eurosurveillance.org/ViewArticle.aspx?Articleld=19671.

(13) McCarthy A. Statement on Meningococcal Disease and the International Traveller. Can Commun Dis Rep. 2015 May;41(5):100-107. http://www.phac-aspc.gc.ca/publicat/ccdr-rmtc/15vol41/dr-rm41-05/com-2-eng.php.

(14) St. John RK, King A, de Jong D, Bodie-Collins M, Squires SG, Tam TWS. Border screening for SARS. Emerg Infect Dis. 2005 Jan;11(1). http://wwwnc.cdc.gov/eid/article/11/1/04-0835.

(15) Public Health Agency of Canada. About CATMAT. Ottawa ON: PHAC; 2015. http://www.phac-aspc.gc.ca/tmp-pmv/catmat-ccmtmv/index-eng.php.

(16) Health Canada. Cruise ship inspection program. Ottawa ON: Health Canada; 2011. http://www.hc-sc.gc.ca/hl-vs/travel-voyage/general/ship-navire-eng.php.

(17) World Health Organization. International Health Regulations 2005. Geneva: WHO; 2005. http://www.who.int/ihr/en/.

(18) Public Health Agency of Canada. International Health Regulations (IHR) (2005). Ottawa ON: PHAC; 2014. http://www.phac-aspc.gc.ca/ep-mu/ihr-rsi/index-eng.php.

(19) International Society of Travel Medicine (ISTM). Canadian Travel Medicine Network of the International Society of Travel Medicine. Dunwoody GA: ISTM; 2015. http://www.istm.org/cantravnet.

(20) Selvey LA, Antão C, Hall R. Evaluation of border entry screening for infectious diseases in humans. Emerg Infect Dis. 2015 Feb;21(2). http://dx.doi.org/10.3201/eid2102.131610.

(21) Cowling BJ, Lau LLH, Wu P, Wong HWc, Fang VJ, Riley S et al. Entry screening to delay local transmission of pandemic influenza A (H1N1). BMC Infect. Dis. 2010;10:82.

(22) Priest P, Jennings L, Duncan A, Brunton C, Baker M. Effectiveness of border screening for detecting influenza in arriving airline travelers. Am J Public Health. 2015 October;105(Suppl 4):S607-S613.

(23) World Health Organization. Public health measures taken at international borders during early stages of pandemic influenza A (H1N1) 2009: preliminary results. Wkly Epidemiol Rec. 2010;85:186-95. 